International Journal of Linguistics, Literature and Translation

ISSN: 2617-0299 (Online); ISSN: 2708-0099 (Print)

DOI: 10.32996/ijltt

Journal Homepage: www.al-kindipublisher.com/index.php/ijltt

\title{
Task-Based Language Teaching to Enhance Learner Communicative Competence in Vietnam: A Matter of Opinion?
}

\author{
Vu Nguyen Dinh Nghia ${ }^{1} 8$ (D) and Nguyen Nhat Quang ${ }^{2}$ (D) $ه$ \\ 'IELTS Instructor, WESET English Center, Ho Chi Minh City, Vietnam \\ ${ }^{2}$ Director, HQT Education Ltd, Ho Chi Minh City, Vietnam \\ $\triangle$ Corresponding Author: Nguyen Nhat Quang, E-mail: nhatquang.ed@gmail.com
}

\begin{tabular}{|c|c|}
\hline ARTICLE INFORMATION & ABSTRACT \\
\hline $\begin{array}{l}\text { Received: July 14, } 2021 \\
\text { Accepted: August 22, } 2021 \\
\text { Volume: } 4 \\
\text { Issue: } 8 \\
\text { DoI: } 10.32996 / \text { ijllt.2021.4.8.22 }\end{array}$ & $\begin{array}{l}\text { This critical review investigates the efficacy in using Task-based Language Teaching } \\
\text { (TBLT) to boost learner communicative competence as TBLT is taking a pioneering } \\
\text { role in developing communicative language in Asia and Vietnam. The application of } \\
\text { TBLT in Vietnam has faced several problems, including exam-based learning } \\
\text { programs, classroom constraints, and teachers' willingness for innovative approaches. } \\
\text { Our in-depth analysis exposed why Vietnamese and Asian teachers cannot initially }\end{array}$ \\
\hline KEYWORDS & trust TBLT, and overcome these challenges to enhance communicative competence. \\
\hline $\begin{array}{l}\text { Asian; communicative } \\
\text { competence; CLT; task; TBLT; } \\
\text { Vietnam }\end{array}$ & $\begin{array}{l}\text { The thorough review of research works in Asia evinced that (1) TBLT can holistically } \\
\text { improve communicative competence and (2) the criticisms against TBLT can be solved } \\
\text { with patience, flexibility, strategic task design, and openness. Then, the authors } \\
\text { suggested a table for TBLT practitioners to consider based on students' level of } \\
\text { proficiency to cater to different teaching contexts and other pedagogic suggestions } \\
\text { to implement TBLT in exam-oriented classes. Finally, we also introduce some research } \\
\text { gaps for further investigation. }\end{array}$ \\
\hline
\end{tabular}

\section{Introduction}

Following the wheel of history, there was a great dominance of English in Vietnam after the socioeconomic reform known as Đổi mới (Renovation) (MOET, 2007). In 1982, English became an official introduction as a compulsory core subject in the secondary and high school's national curriculum (Hoang, 2018). Since then, The EFL education in Vietnam has faced many problems, including (1) the limited number and the under-qualification of both Vietnamese and foreign English teachers, (2) low-quality coursebook design, (3) exam-oriented curriculum, (4) physical classroom and teaching facility constraints, (6) obsolete teaching materials, (7) teachers' resistance against renovation (8) and the lack of communicative opportunities. (Hoang, (2018); Pham, (2005); Vu \& Burns (2014)). It is worth note-taking that one of the unique challenges in fostering ELT in Vietnam is students' low communicative competence (Hoang, 2018). Thus, the MOET has set a goal to improve the communicative competence of Vietnamese EFL learners by the year 2020 (Nguyen, 2018). This reality calls for a holistic implementation of more innovative teaching approaches, Task-based Language Teaching (Ellis, 2018). The need to improve communication skills exploiting TBLT also rises in many other Asian nations, including China (Liao, 2014), South Korea (Choi, 2007), Japan (Kiernan \& Aizawa, 2004), and (Nunan, 2003). Years of research have proved its effectiveness in enhancing students' communication in general (Le \& Nguyen (2012), Nguyen (2013), Barnard \& Viet (2010)). Nonetheless, while TBLT often receives appraisals as an innovative approach emphasizing practical use of authentic language, Butler (2011) argued that TBLT needs a certain degree of adaptation before being truly applicable. Admittedly, in the context of Vietnam, TBLT receives a variety of concerns regarding the conceptualization of task-based language teaching, inadequate materials facilitating TBLT, class size and time allocation, and its effectiveness in mix-level or exam-oriented classes, teachers' lack of TBLT expertise and, experience (Pham (2000), Barnard \& Viet (2010), Viet (2014), Nguyen, Le, \& Barnard (2015), Yen (2016), Cao (2018)).

\section{K C AL-KINDI CENTER R D FOR RESEARCH AND DEVELOPMENT} Your gateway to world-class research

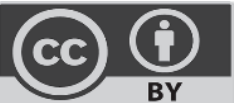

Published by Al-Kindi Center for Research and Development, London, United Kingdom. Copyright (c) the author(s). This open access article is distributed under a Creative Commons Attribution (CC-BY) 4.0 license 
The literature review exposes a significant gap in research connecting the TBLT and learner communicative competence to the development of learner communicative competence in the specific context of Vietnam (Bunmak, 2017; Na, 2017). Also, as TBLT is not yet widely implemented in state schools, this method indeed still stirs up the opposition, hesitation, and apprehension among the teaching staff. Therefore, within this article, the authors aim to dig deeper into the teacher's perceived problems in applying TBLT in enhancing communicative competence in Vietnam and justify its appropriateness in the Vietnamese context.

The first part is dedicated to contextualizing the current ELT situation in Vietnam before the authors delineate the related theoretical concepts related to TBLT and communication competence. In the following part, this article investigates the concerns shared by Vietnamese teachers that hinder their application of TBLT in enhancing learner communicative competence. We then refer to how other researchers in other Asian countries addressed similar problems to testify the academic and practical rigor of this approach. Subsequently, we conclude on the applicability of TBLT in enhancing Vietnamese learner communicative competence before drawing attention to a cluster of pedagogical implications and future research recommendations in the last section.

\subsection{An in-depth briefing of communicative competence}

Before going into details regarding the applicability of TBLT in the Vietnamese context, the authors find it necessary first to elucidate the definition and the role of communicative competence in ELT. Chomsky (1965) coined the term linguistic competence, which was explained as producing grammatically accurate utterances. However, linguists later disagreed by arguing that the ability to communicate effectively cannot be measured narrowly via competence in linguistics (Harbermas, (1970); Hymes, (1972)). Specifically, Hymes (1966) initially introduced the term communicative competence to react against the inadequate theory of Chomsky. Also, Hymes (1972) added sociolinguistic competence, which refers to the appropriate use of language in terms of social acceptance. Since then, numerous scholars in the world of linguistics have tried to redefine the term communicative competence. Wiemann (1977) and Spitzberg and Cupach (1989) developed one of the initial models of communicative competence. Wiemann (1977) proposed five dimensions, including (1) affiliation or support, (2) social relaxation, (3) empathy, (4) behavioural flexibility, and (5) interaction management skills. The subsequent theoretical development of communicative competence was contributed by Canale and Swain (1980), who renamed linguistic competence as grammatical competence, and at the same time, they proposed strategic competence. This model was again developed by Canale (1983) by adding discourse competence. Linguistic competence was renamed by Bachman (1990) as language competence, which includes grammatical and discourse competence and pragmatic competence. Bachman (1990) also helped to develop strategic competence. Finally, Littlewood (2001) structuralized communicative competence in four factors, involving (1) linguistic competence, which is the ability to demonstrate the comprehension of language with grammatical and lexical accuracy; (2) sociolinguistic and sociocultural competence, which refers to the social and cultural suitability in the use of language; (3) pragmatic competence, which means how to deliver a speech effectively in a contextually acceptable manner; (4) discourse competence is the last factor, which represents the ability to communicate at-length without or with little hesitation.

\subsection{The nature of task-based language teaching}

TBLT evolved as a branch of Communicative Language Teaching (CLT), a teaching method that underscores the role of communication. According to Ellis (2003), TBLT concentrates on the practical use of the target language by making students use the language. Therefore, a typical lesson plan applying TBLT does not usually include the target language features such as a grammatical point, but it focuses on completing the tasks (Ellis, 2003). There are four criteria for an activity to become a task:

1. The language is used rather than being learned, and also, there is a must to focus on meaning.

2. Tasks must involve a certain level of gaps, for example, information gap, reasoning gap, or opinion gap.

3. Rather than using the linguistic factors equipped beforehand, students must use their linguistic and non-linguistic resources to complete the tasks.

4. The assessment is based on the outcome's achievement rather than the accuracy of language.

(Ellis, 2000)

These tasks come in two categories: real-world tasks and pedagogic tasks. Within a TBLT lesson, there are usually three consecutive phases, namely pre-task, main-task, and post-task. In the pre-task phase, students are prepared before the task performance, and then the main-task phase is when students engage in the task activities to facilitate language acquisition. The teachers only provide extra help if needed because it is a student-centered approach (Niemeier, 2017). The final step is known as 
the post-task phase; the students review each other's performance and address any linguistic mistakes during the main-task phase.

\section{The critics against the use of TBLT to improve communicative competence}

Despite being an innovative approach, TBLT has been continually criticized due to its inability to improve students' communicative competence within the Vietnamese context. The first challenge for TBLT was conflict in pedagogical beliefs. The conventional view of teaching and learning in Asia had the foundation on literacy, teacher-centered methodology, and teaching the knowledge presented in textbooks and course books $(\mathrm{Hu}, 2002)$. The thousand-year presence of Confucianism in many Asian countries, and particularly Vietnam, has affected the learning culture of Vietnamese students. Foremost among the Confucianistic tenets about learning was about the learner codes of conduct in the classroom, advocating the so-called morals that students must obey teachers without inquiry. Until now, Vietnamese teachers still need to perform Multi-functionally as academic, behavior, and moral educators (Mai, 2017). They believe that they are mainly responsible for providing the student with knowledge while disciplining the classroom so that the students do not interfere with the teaching and learning practices of the nearby class. On the contrary, an innovative approach such as TBLT was developed based on the belief that teaching practices nowadays should be learner-centered and the practicality of knowledge should be prioritized (Ellis, 2018). In other words, the teachers will not have the role of knowledge providers who rely on their teaching on the course books. Moreover, students have to be seen as self-explorers when learning. These conflicts in pedagogical perspectives remain a daunting challenge for Asian educational practitioners to adapt to TBLT (Butler, 2011; Chow \& Mok-Cheung, 2004; Hu, 2002). The case is also true in the Vietnamese EFL setting (Hoang, 2018). According to Cao (2018), Vietnamese EFL teachers still keep giving explicit grammar and vocabulary lessons based on the assigned curriculum with the Presentation-Practice-Produce method (Viet, 2014). Even after the teachers participated in TBLT training, they ended up teaching conventionally using the grammar-translation method (Hoang, 2018). This mismatch in notions hinders the effectiveness of TBLT in enhancing students' communicative competence (Le, 2014).

Another problem facing TBLT is challenges in assessment. TBLT focuses more on formative assessment (Ellis, 2018) rather than having students sit formal exams. In sharp contrast, a large percentage of education systems in Asia and Vietnam still employ heavy grammar-based examinations (Butler, 2011; Hoang, 2018; Phan, 2017). This disparity led to several obstacles when the approach was applied. Firstly, the teachers will hesitate to use TBLT because they have to bear the pressure to teach students how to perform well in the grammar-focused assessments (Lin \& Wu, 2012; Le, 2014; Cao, 2018). Secondly, the students are less likely to be involved in communicative activities as they are not tested in exams, which means the burden to gain an impressive academic record is still enormous. TBLT has received the same concerns among parents because the English courses are usually exam-oriented (Phan, 2017), which is contradictory to the primary aim of CLT and TBLT. The Asian and Vietnamese students and teachers are reluctant to focus on communicative competence because the examination for college entrance emphasizes reading comprehension, grammar, and vocabulary resources (Butler \& lino, 2005; Van Canh \& Barnard, 2009). Furthermore, many local teachers do not want to change their teaching practice or play a role in the innovative movement in teaching practice (Tomlinson \& Dat, 2004). Therefore, the teachers hesitantly apply the approach and focus on teaching students grammatical rules to perform well in the examinations. Under the peer and parental pressure, students cannot have enough space available for communicative lessons and tasks, which in turn prevent sociolinguistic and sociocultural competence, pragmatic competence, and discourse competence from developing.

The next challenge is classroom practices and management. Because TBLT focuses on meaningful communication and students' linguistics resources (Ellis, 2003), it imposes a daunting task for teachers to use tasks for several reasons, such as big class size (Cao, 2018). College students and adult learners lack adequate linguistic resources to perform tasks as expected, leading to under-performance and task in-completion (McDonough\&Chaikitmongkol, 2007; Le, 2014; Do, 2017). Some studies even reported that the learners use their first language when working on tasks in groups, leading to the degradation of TBLT effectiveness in improving communicative competence. When students are performing tasks in their first language, by no means can sociolinguistic and sociocultural competence and discourse competence in the target language develop. Also, Sakui (2004), Nishino (2008), and Yen (2016) reported other problems, which are big class size and insufficient in-class time. More specifically, the number of students in each class in Asia is still more than the advisable index to apply communicative approaches. When the large is crowded, it is hard for the teachers to play roles as task-facilitators and counselors. These hindrances impose difficulties in applying TBLT to improve students' communicative competence (Canh \& Barnard, 2019). With insufficient time allocated for a class lesson and many students involved in TBLT activities at once, it is hard for students to improve discourse competence. After all, the ability to communicate at length has to improve gradually in a certain period. Less time allocated means less chance to develop discourse competence (Hoang (2013) and Nguyen et al. (2014)). In conclusion, there are three major hindrances in applying TBLT in the context of Vietnam in order to boost students' communicative competence, namely (1) the conflicts in pedagogical ideology, (2) over-obsession with testing and examinations, (3) difficulties in classroom management. These problems in turn will prohibit the development of important components of communicative competence. 


\section{The empirical and theoretical rebuttal to the accusations of TBLT in improving communicative 3.1 Initial perceptual resistance to innovation is predictable in education}

The fact that TBLT can improve communicative competence despite initial conflicts in ideology after a period of kick-off is proven in Japan, Turkey, and Indonesia. Educators have to admit that psychological inertia is ubiquitous in education whenever changes take place in the classroom ( $D^{\prime}$ Eon, 2013). To be more specific, despite its advantages, an innovative approach still has to encounter opposition when being introduced. With a conservative nature in teaching beliefs and methods, some educational practitioners have not accepted TBLT since it was first introduced ( $D^{\prime} E$ En, 2013). The opposition came from many roots. The first one is teachers' conservatism, for they hold conservative beliefs based on their years of teaching experience that conventional methods are good enough for their teaching practice even without using new approaches. Secondly, Vietnamese local teachers are often underpaid, especially in state-run educational organizations (Hoang, 2018). Thus they would not spend time improving the teaching practice, without a promise for financial benefits. Thirdly, parents and students cannot trust an initiative if they do not see immediate results in the examination. Meanwhile, TBLT focuses on incidental learning that takes a long period of acquisition before students' results in performance can be seen (Ellis, 2018).

It is, however, possible to overcome psychological inertia with time and motivation. Global educational innovation has seen similar resistance whenever initiatives were introduced. Liberal education was resisted in the Western world (Edmundson, 1997; Hohendahl, 2011), and the no-homework movement in some countries also raised some public concerns (Corno, 1996; Hough, 2014). This case also rings true in the ELT field when the Presentation-Practice-Produce method also criticised its introduction (Anderson, 2017). Eventually, by the time the resistance phase was over, empirical evidence would have sufficed to justify the rationale of a new approach. Consequently, students, parents, and society would become more open to the innovative approaches that yielded them more substantial benefits. With regard to TBLT, in Japan, Anthony (2012) and Kaneko (2008) conducted studies on the effectiveness of TBLT to measure if this approach can boost students' communicative competence and speaking performance. Predictably, at first, students showed disagreement when being asked to engage in communicative activities and tasks, they stated in the questionnaire that since high school, they were familiar with traditional methods such as Present-Practice-Produce and the teachers are the main source of knowledge, also, what they learned was mostly from the assigned course books. It is explainable that conventional teaching practices and beliefs led to the fact that students coming to college were mostly well-equipped with grammatical knowledge and lexical resources, but they were incapable of utilizing those linguistic resources to produce at-length speech effectively. Eventually, with motivation from the teachers and the level of interest from tasks, students became more open with the new approach, resulting in the fact that they could make longer sentences and generate more fluent discourses with a higher degree of both syntactic complexity and accuracy. The same situation happened in Turkey, according to Bava and Gheitanchian (2017), the group of people who conducted the research has overcome their conflicts in notion, they first acknowledged the importance of student-centered learning by allowing multimediaincorporated materials to be used during the research period. Similar to Japan, Turkish students showed their unfamiliarity with TBLT and the student-centered approach for the same reasons as their Japanese counterparts. However, with appropriate activities and teachers' attitudes, students gradually improved their linguistic, pragmatic, and discourse competence. The conservative beliefs and practices from Indonesian teachers and students were mitigated by the fact that teachers were less demanded to bear the burden of completing the syllabus with coursebooks and having students do exercises on grammar and vocabulary (Rohani, 2013). Thus, they were given more freedom to design TBLT tasks that could help students to switch their communication strategies. Students' verbal performance and linguistic competence and pragmatic competence were boosted, contributing to the general improvement in communicative competence.

\subsection{TBLT plays a seminal role in developing a holistic system of community competence}

Years of research has proven the efficacy of TBLT in developing holistically four aspects of communicative competence. In action research with fifteen sixth graders in Spain by Herraiz-Martínez (2018), the students participated in five types of computerassisted TBLT activities. The comparisons between the pretest and post-test results demonstrated a significant improvement in pragmatic competence. This research supports the two-phase project whose first phase investigates the effects of TBLT on learner pragmatic competence development in Iran by Noroozi (2012). In phase one, the experimental phase, after twelve sessions, the experimental group became more versed in illocutionary force of speech act than the control group, which indicated a superiority in pragmatic competence. Kanca and Widanta (2017) found that the participants could develop their sociolinguistic, discourse, and strategic competence just after a two-section period.

Linguistic competence is the aspect that TBLT receives specifically many criticisms from the public stating that it is inferior to other grammar-based language teaching approaches. The misconception that TBLT failed to help with 'grammar' was presented in Somawati et al. 's article (2020). After ten sessions, the research concluded that there was an increase in L2 fluency, pronunciation and comprehension, but not grammar. This conclusion means that TBLT develops communicative competence in general, but it was not able to develop accuracy. This is, however, a misunderstanding. Utilizing the implicit instruction and 
learning mechanism, TBLT takes more time than other approaches that advocate explicit teaching. That is, TBLT prioritizes fluency over accuracy in language acquisition and accuracy will increase with time. Thus, as stakeholders of the exam-oriented courses need to wait and see the results to take place, they may have the misunderstandings that TBLT is not as effective as other methods in perfecting the learner linguistics competence in addition to the other competences. In reality, other empirical research works proved the opposite to the common misunderstandings. While implicit learning needs a longer period to develop the learner's interlanguage and their linguistic competence, those who learn English with this implicit mechanism can become more native-like than their counterparts (Ellis, 2015). Although the learners and the public in which the research was conducted expressed their doubt in the effectiveness of the TBLT approach at first, the way TBTL facilitated students' communicative competence changed their attitude. For example, in Nithitwaraphakun (2019), Thai business people taking part in TBLT initiatives thought that they were not in favor of an approach offering them with neither paper examination nor learning the vocabulary. The participants' level of hesitation and opposition dropped when teachers designed tasks that were interesting and related to real-life experiences. At the post-test phase, the students performed more naturally and fluently in the speaking assessment, reported that they could improve their listening, and needed a shorter amount of time to generate appropriately and accurately vocabulary for speaking. This improvement means that TBLT is capable of improving students' linguistic competence besides other competencies. Another research by Rajabi and Hashemian (2015), TBLT was very fruitful in enhancing students' linguistic and metalinguistic knowledge regarding problematic grammar points. The TBLT classroom even had more significant positive impacts on learner linguistic accuracy than the blended classroom in this research. The research by Kanca and Widanta (2007) also concluded that TBLT can improve learners' grammatical accuracy regarding past tense pattern, conjunction, preposition, article, noun, adjective, and adverb phrase. These findings prove that, in fact, still help students with the examinations.

\subsection{TBLT is the solution to time-constrained syllabus and classroom limitations}

Research works in Asia show that TBLT can cater to different classroom difficulties such as inadequate class time, and big class size. TBLT, in the face of these constraints, can still positively affect students' communicative competence if the teachers have indepth knowledge ( $\mathrm{Na}$, 2017). The problems of class size were also overcome in Tang et al. (2015), Yang (2009), Yahya (2019). In the research by Tang et al. (2015), the number of students and class time was 76 Chinese students with 15 weeks, 93 Taiwanese EFL college students with 12 weeks, and 59 Malaysian university students respectively. By providing students with pair and group discussion as well as group presentation, the researchers were able to vary the interactional patterns that enhance the students' opportunity to practice authentic interaction and communication, thus the overall enhancement in communicative competence. In retrospect, the key to successful classroom management and lesson planning with TBLT for such unfavorable classroom conditions is the teacher's ability, flexibility, and experience while monitoring and evaluating students. On the contrary to the Vietnamese teachers' concern regarding time constraints, TBLT is flexible in nature as the task sequence is not fixed. Therefore, teachers can adjust their lesson plan according to their time allocation and the each task's value for the students in specific contexts (Hai-Yan, 2014). Besides, as the teacher can diversify the classroom interaction pattern, the large number of students in a class is still manageable with the appropriate task sequencing.

\subsection{The appropriate and strategic choice of tasks can facilitate mix-level classes}

The Japanese students taking part in the studies of Kaneko (2008) and Anthony (2012) showed various levels of proficiency, while students in Kaneno (2008) study has different levels of communicative competence, from low to intermediate, the majority of students in Anthony (2012) study were low in proficiency. Nevertheless, with the suitable arrangement of task complexity and Pre-task activities, students could make longer and more complex utterances and sentences, proof that linguistic competence was improved, they could even enhance their discourse and pragmatic competence. Depending on students' communicative competence at individual levels, it is necessary to modify task complexity, while high-competence students could improve linguistic complexity with complicated tasks. The problem of low-proficiency students using L1 during tasks performance was also overcome when teachers give students simple-input linguistic items and the modification of while-task activities with the input-based psychological requirement, closed task outcomes, here-and-now visual support, single demand, and simple outcomes (Kaneko (2009), Anthony (2012), Nithitwaraphakun (2019), Yahya (2019)). All these studies concluded positive results when TBLT was applied, with evidence in (1) students' enormous improvement in linguistic complexity, fluency, and pronunciation, (2) speaking performance, (3) improvement in listening comprehension, (4) dramatic improvement on students' lexical resources, and (5) students' positive attitude, joyfulness, and confidence. The improvement in different aspects proven above claimed that linguistic competence was improved (the language use and lexical items were more complex), discourse competence was also improved (students were more fluent and comprehended more listening input). Finally, the improvement in pragmatic competence was explained by the fact that students were more confident and had enjoyment, leading to their speech being more contextually acceptable. 


\section{Conclusion and pedagogical implications}

In general, ELT in Vietnam has still been through a transitional phase and there are still many obstacles to overcome. But it was a promising movement that MOET acknowledged the importance of enhancing communicative competence of Vietnamese learners. We have discussed two main issues, including (1) concerns raised by local Vietnamese teachers on challenges that TBLT faces in enhancing learners' communicative competence, and (2) how some Asian nations with similar problems to Vietnam have employed TBLT successfully to enhance learners' communicative competence. It is evident that there are possibilities to apply TBLT in Vietnam to meet the national target of boosting English learners' communicative competence. Being a ConfucianHeritage country like Japan and China, the pedagogical ideology in Vietnam is still influenced enormously by Confucianism, the students are also not familiar with learner-centered approach which requires them to actively contribute to the lesson. The teachers, therefore, are reluctant to modify their educational beliefs and teaching practice. The second concern is challenges in assessment, due to mismatch in how language learning is assessed, the examinations, particularly the most important one for students which is the University Entrance Exam taken after $\mathrm{K}-12$, aim to test students' ability to comprehend reading text, or to do accuracy-based exercise related to grammar and vocabulary. The third concern comes from classroom practices and management. The English class at Asian state-run schools were criticized due to the excessive number of students and inadequate time assigned for each lesson, making integrating TBLT lessons extremely difficult for the teachers. Also, students' linguistic resources are varied, which means the activities required to suit these mix-leveled classes are hard to design. Our review concludes that TBLT can always be an effective and innovative approach for improving students' communicative competence. The resistance due to disagreement in teaching beliefs can soon be overcome if teachers, students, parents, and the whole community give TBLT a chance to prove its effectiveness. Research papers aiming to measure the effectiveness of TBLT on communicative competence have been conducted in several countries around the world. The participants in TBLT classes can enhance their linguistic, sociolinguistic, discourse and strategic competence. Linguistic fluency can be effectively improved with TBLT and accuracy in language acquisition will gradually improve over the time. In terms of time-constrained syllabus and classroom limitations, teachers can implement different interactional patterns between students so that they can practice authentic linguistic interaction with appropriate activity designs. Because TBLT is flexible in task sequence, the teachers can adjust their TBLT lessons to fix their available teaching time. To deal with mixed-level classes, researchers in Asia proposed that task complexity should be modified according to the task features described in the following table.

Suggestions for task-design features at different level of competence

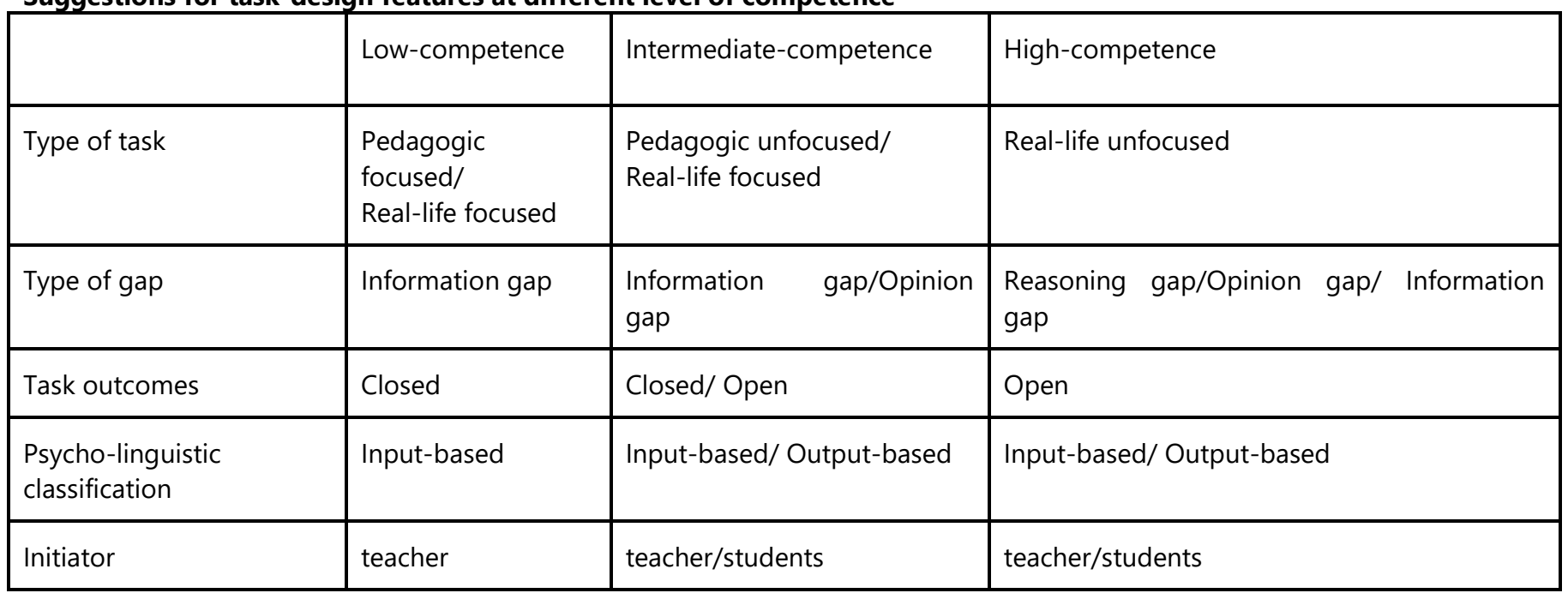

The authors suggest that the modification of tasks components are important. For students with a low level of competence, the tasks should be simple with pedagogic-based activities and information gaps. The two other kinds of information gap, namely opinion gap and reasoning gap, are suitable for intermediate and advanced students as they require more logical ability and critical thinking. The most challenging kind of gap is the reasoning gap (Ellis, 2018), which should only be suitable for advanced students. Also, they should receive instructions from the teachers from the early stages of learning. Closed task outcomes are also suggested as they can be easy to manage students' productivity. The more proficient students, on the other hand, can gradually engage in tasks with more complicated components following their level.

It is unlikely that Asian and Vietnamese students and teachers will be released from the burden of examination as assessment in the foreseeable future, and the presence of exam-oriented classes will continue to be a norm, at least in the short term. Therefore, it is suggested to suitably and subtly integrate TBLT and PPP in focus-on-form lessons, so that students can enjoy 
communicative and authentic activities and prepare for examinations at the same time. There is a need for intensive efforts from the teachers, educational policy-makers, practitioners and other shareholders to welcome changes in pedagogy. This will lead to positive changes when not only TBLT but also other communicative approaches will be employed, leading to chances for students to learn the language practically and enjoy more authority in their learning at the same time (Butler, 2011).

\section{Research gaps and limitations}

While there is ample empirical and theoretical evidence to prove the efficacy of TBLT on communicative competence development in Asia and Vietnam, it is admitted that the many research included in this critical review are still small-scaled and localized. The time allocation of some research included in this paper cannot fully address the U-shape development in second language acquisition with the aid of TBLT. Thus, the authors here address the need to re-investigate the effectiveness with TBLT in Vietnam and Asia using a longitudinal research design as the nature of TBLT prioritizes the development of fluency over accuracy.

With regard to the outbreak of Covid 19 and the emergency shift to computer-assisted and mobile-assisted classrooms raised more questions about the efficacy of TBLT and other communicative language teaching approaches. It is irrefutable that the physical distance between students and teachers while social-distancing causes many problems with contemporary methods and approaches. When human interaction and communication transform into a cyber process, the questions regarding how to define communicative competence also emerges. The overarching idea revolves around the possibility that researchers need to add any instrumental or technological competence to the model of communication competence. Whether teaching online platforms with TBLT can stimulate student communicative efficacy is another under-researched realm.

\section{References}

[1] Anderson, J. (2017). A potted history of PPP with the help of ELT Journal. ELT Journal, 71(2), 218-227. https://doi.org/10.1093/elt/ccw055

[2] Anthony, G. C. (2012). Task-based language teaching in a low-proficiency Japanese university context. Hachinohe University Journal, 45, 4150. http://jairo.nii.ac.jp/0305/00000118/en.

[3] Bachman, L. (1990). Fundamental considerations. Oxford University Press.

[4] Barnard, R., \& Viet, N.G. (2010). Task based language teaching (TBLT): A Vietnamese case study using narrative frames to elicit teachers' beliefs. Language Education in Asia, 1, 77- 86.

[5] Bava Harji, M., \& Gheitanchian, M. (2017). Effects of multimedia task-based teaching and learning approach on EFL learners' accuracy and fluency and complexity of oral production. The Turkish Online Journal of Educational Technology, 16(2), 25-34.

[6] Bunmak, N. (2017). The Influence of Task-based Learning on ELT in ASEAN Context. Language Education and Acquisition Research Network, 10(1), 201-209. https://so04.tci-thaijo.org/index.php/LEARN/article/view/135973

[7] Butler, Y. G., \& lino, M. (2005). Current Japanese reforms in English language education: The 2003 'Action Plan'. Language Policy, 4(1), 2545.

[8] Butler, Y. G. (2011). The Implementation of Communicative and Task-Based Language Teaching in the Asia-Pacific Region. Annual Review of Applied Linguistics, 31, 36-57.

[9] Canale, M., \& Swain, M. (1980). Theoretical bases of communicative approaches to second language teaching and testing. Applied Linguistics, 1(1), 1-47.

[10] Canale, M. (1983). From communicative competence to communicative language to pedagogy. In J. Richards, \& R. Schmidt (Eds.), Language and communication, 2-27. London Group Ltd.

[11] Canh, L. V., \& Barnard, R. (2009). Curricular innovation behind closed classroom doors: a Vietnamese case study. Prospect, 24(2), 20e33

[12] Cao, T.H.P. (2018). Task-based language teaching: Affordances and challenges in TBLT implementation at the Vietnamese tertiary level. The Journal of Asian TEFL, 15 (2), 510- 515. DOI: 10.18823/asiatefl.2018.15.2.1.510

[13] Choi, Y. H. (2007). The history and the policy of English language education in Korea.

In Y. H. Choi \& B. Spolsky (Eds.), English education in Asia: History and policies, 33-66. Asia TEFL.

[14] Chomsky, N. (1965). Aspects of the Theory of Syntax. Cambridge. MIT Press.

[15] Chow, A., \& Mok-Cheung, A. (2004). English language teaching in Hong Kong SAR: Tradition, transition, and transformation. In W. K. Ho \& P. Y. L. Wong (Eds.), English language teaching in East Asia today, 150-177. Eastern Universities Press.

[16] Corno, L. (1996). Homework Is a Complicated Thing. Educational Researcher, 25(8), 27-30. https://doi.org/10.3102/0013189X025008027

[17] D'Eon, PhD, M. (2013). The challenges of educational change: cultural and psychological inertia. Canadian Medical Education Journal, 4(2), e1-e3. https://doi.org/10.36834/cmej.36698

[18] Đô Na, C. (2017). Task-Based Language Teaching in Vietnam: Misunderstandings and Suggestions. Tạp Chí Khoa Học Đại Học Đà Lạt, 7(4), 587. https://doi.org/10.37569/dalatuniversity.7.4.303(2017)

[19] Edmundson, K. (2000). Issues in after-school youth development programming. In Danish, S.J. \& Gullotta, T. (Eds.). Developing competent youth and strong communities through after-school programming (pp. 217-238). Washington, DC: CWLA Press.

[20] Ellis, R. (2000). Task-based research and language pedagogy. Language Teaching Research, 4(3), 193-220. https://doi.org/10.1177/136216880000400302

[21] Ellis, R. (2003). Task-based language learning and teaching textbook. Curtin Online Library.

[22] Ellis, R. (2015). Understanding second language acquisition. Oxford, UK: Oxford University Press.

[23] Ellis, R. (2018). Task-based language teaching textbook. Curtin Online Library. 
[24] Hai-Yan, M. (2014). The task-based teaching of writing to big classes in Chinese EFL setting. English Language Teaching, 7(3), 63-70. https://doi.org/10.5539/elt.v7n3p63

[25] Habermas, J. (1970). Toward a theory of communicative competence. In H.P. Dreitzel (Ed.), Recent Sociology No. 2, 115-148. Macmillan.

[26] Herraiz-Martínez, A. (2018). Technology and task-based language teaching (TBLT): Exploring pragmatics. In the International Journal of Education and Development using Information and Communication Technology (IJEDICT) (Vol. 14, Issue 2).

[27] Hoang, V. V. (2013). The current situation and issues of the teaching of English in Vietnam. Retrieved from http://rcube.ritsumei.ac.jp/bitstream/10367/4129/1/LCS 22 1pp7-18 HOANG.pdf.

[28] Hoang, V. (2018). The Current Situation and Issues of the Teaching of English in Vietnam, 22, 7-18. https://www.researchgate.net/publication/326718789 The Current Situation and Issues of the Teaching of English in Vietnam.

[29] Hohendahl, P. U. (2011). Humboldt revisited: Liberal education, university reform, and the opposition to the neoliberal university. New German Critique, 38(113), 159-196. https://doi.org/10.1215/0094033X-1221812

[30] Hough, L. (2014). Are You Down With or Done With Homework? Harvard Graduate School of Education. https://www.gse.harvard.edu/news/ed/12/01/are-you-down-or-done-homework

[31] Hu, G. (2002). Potential cultural resistance to pedagogical imports: The case of communicative language teaching in China. Language, Culture and Curriculum, 15, 93-105.

[32] Hymes, D. (1966). On communicative competence. Paper originally read at the Research Planning Conference on Language Development among Disadvantaged Children, Yeshiva University, June 1966. Reprinted, in part, in C.J. Brumfit \& K. Johnson (Eds.). (1979). The Communicative Approach to Language Teaching. Oxford: Oxford University Press.

[33] Hymes, D. (1972). On communicative competence. In J.B. Pride and J.Holmes (Eds.), Sociolinguistics, 269-285. Penguin.

[34] Kanca, I. N., \& Widanta, I. M. R. J. (2017). Can Task-Based Learning Improve Students' Communicative Competence? International Journal of Language and Linguistics, 4(4). www.ijllnet.com

[35] Kaneko, E. (2008). An analysis of oral performance by Japanese learners of English. (Doctoral Dissertation)., The University of Wisconsin, USA. Wisconsin.

[36] Kiernan, P., \& Aizawa, K. (2004). Cell phones in task based learning: Are cell phones useful language learning tools? ReCALL, 16, 71-84.

[37] Le, T. N., \& Nguyen, H. B. (2012). Task-based language learning and student motivation in vocabulary acquisition. Language Education in Asia, 3(1), 106-120.

[38] Le, V. T. (2014). Factors affecting Task-based language teaching from teachers' perspectives. Study in English language teaching, 2(2), 108122.

[39] Liao, X. (2004). The need for communicative language teaching in China. ELT Journal, 58, 270-273.

[40] Lin, T. B., \& Wu, C. W. (2012). Teachers' perceptions of task-based language teaching in English classrooms in Taiwanese junior high schools. TESOL Journal, 3(4), 586-609.

[41] Littlewood, W. (2011). Communicative language teaching: An expanding concept for a changing world. In E. Hinkel (Ed), Handbook of research in second language teaching and learning. (2), 541-557. Routledge.

[42] Mai, H. T. N. (2017). Contextual Factors Affecting The Implementation of Communicative Language Teaching in Vietnam. EFL Journal, 2(2), 103-113

[43] McDonough, K., \& Chaikitmongkol, W. (2007). Teachers' and learners' reactions to a task based EFL course in Thailand. TESOL Quarterly, 41, 1071-1132.

[44] MOET (Institute for Educational Strategies and Curriculum Development). (2007). English curriculum. Hanoi: Educational Publishers.

[45] Nguyen, T. (2013). Tasks in action in Vietnamese EFL high school classrooms: The role of rehearsal and performance in teaching and learning through oral tasks. (Doctoral dissertation), Victoria University of Wellington, New Zealand. http://hdl.handle.net/10063/3111

[46] Nguyen, T. H., Warren, W., \& Fehring, H. (2014). Factors affecting English language teaching and learning in higher education. English Language Teaching, 7(8), 94-105.

[47] Nguyen, V. G., Le, V. C., \& Barnard, R. (2015). "Old wine in new bottles": Two case studies of task-based language teaching in Vietnam. In M. Thomas \& H. Reinders (Eds.), Contemporary task-based language teaching in Asia (pp. 68-86). London, UK: Bloomsbur.

[48] Nguyen, T. V. (2018). Project 2020 and professional development for high school EFL teachers in Vietnam. In K. Hashimoto, \& T. V. Nguyen (Eds.), Professional Development of English Language Teachers in Asia, 105-118. Routledge.

[49] Niemeier, S. (2017). Task-based Grammar Teaching of English - Where Cognitive Grammar and Task-based Language Teaching Meet. Narr.

[50] Nishino, T. (2008). Japanese secondary school teachers' beliefs and practices regarding communicative language teaching: An exploratory survey. JALT Journal, 30, 27-50.

[51] Nithitwaraphakun, K. (2019). The Application of Task-based Language Teaching to the English Training Course for One Tambon (Village) One Product (OTOP) Entrepreneurs in Thailand. The New English Teacher, 13(2). Assumption University of Thailand. Thailand.

[52] Noroozi, I. (2012). On the effect of task-based language teaching on the pragmatic competence (Illocutionary force) of the Iranian male and female students. Theory and Practice in Language Studies, 2(10), 2081-2089. https://doi.org/10.4304/tpls.2.10.2081-2089

[53] Nunan, D. (2003). The impact of English as a global language on educational policies and practices in the Asia-Pacific region. TESOL Quarterly, 37, 589-613.

[54] Pham, H. H. (2000). Traditional versus modern teaching methods. Teacher's Edition, 2, 20-23.

[55] Pham, H. (2005). University English classrooms in Vietnam. ELT Journal, 59(4), 336-338. https://doi.org/10.1093/elt/cci063.

[56] Phan, L. L. H. N. (2017). Challenges / Constraints in Teaching Today ' S English in Vietnam: Teachers ' Voices. TESOL Conference $2017,1-11$.

[57] Rajabi, B., \& Hashemian, M. (2015). A Comparative Study of the Effectiveness of Two Methods of Teaching Resumptive Pronouns in Writing: TBLT and Blended Learning. English Language Teaching, 8(9). https://doi.org/10.5539/elt.v8n9p196

[58] Rohani, S. (2013). Positive versus negative communication strategies in task-based learning. TEFLIN Journal, 24(2), 158-179.

[59] Sakui, K. (2004). Wearing two pairs of shoes: Language teaching in Japan. ELT Journal, 58, 155-163. 
[60] Somawati, N. P., Kanca, I. N., \& Widanta, I. M. R. J. (2020). Implementation of Task-Based Language Teaching: To What Extent is Communicative Competence Achieved? 572-577. https://doi.org/10.2991/icss-18.2018.117

[61] Spitzberg, B. H., \& Cupach, W. (1989). Handbook of Interpersonal Competence Research. SpringerVerlag.

[62] Tang, H., Chiou, J.S., \& Jarsaillon, O. (2015). Efficacy of task-based learning in a Chinese EFL classroom: A case study. English Language Teaching, 8(5), 168-176.

[63] Tomlinson, B., \& Bao, D. (2004). The contributions of Vietnamese learners of English to EFL methodology. Language Teaching Research, $8(2), 199-222$.

[64] Van Canh, L., \& Barnard, R. (2009). Curricular innovation behind closed classroom doors: a Vietnamese case study. Prospect: An Australian Journal of TESOL, 24(2), 20-33.

[65] Viet, N. G. (2014). Forms or meaning? Teachers' beliefs and practices regarding task-based language teaching: A Vietnamese case study. The Journal of Asia TEFL, 11(1), 1-36.

[66] Vu, N., \& Burns, A. (2014). English as a medium of instruction: Challenges for Vietnamese tertiary lecturers. Journal of Asia TEFL, 1-33.

[67] Wiemann, J. M. (1977). Explication and test of a model of Communicative Competence. Human Communication Research (3), $195-213$.

[68] Yahya, M. Y. (2019). Improving speaking performance and L2 motivation through task-based language teaching on Malaysian undergraduate students. (Doctoral Thesis). University of Reading, Malaysia.

[69] Yang, J. Y. (2009). Integrating the task-based approach and the grammar translation method with computer-assisted instruction on Taiwanese EFL college students' speaking performance. Bookman.

[70] Yen, P. H. (2016). Challenges of shifting to task-based language teaching: A story from a Vietnamese teacher. Can Tho University Journal of Science, 2(1), 37-45. 